\title{
The Impact of Interpersonal Communication toward Customer Satisfaction: The Case of Customer Service of Sari Asih Hospital
}

\author{
Novalia Agung W. A. ${ }^{1, *}$ \\ ${ }^{1}$ School of Communication, University of Prof. Dr. Moestopo (Beragama), Jakarta, Indonesia
}

\begin{abstract}
Customer Service has a considerable role. In order to retain the loyal customer, their attitude should be friendly, courteous, patient, and willing to listen to what customer said. Good Customer Service should create customer satisfaction for it is the presence of customer determines the existence of the company. This condition is also true for hospital as it is the case of Sari Asih Hospital in Ciledug, Indonesia. Sari Asih Hospital is a private hospital whose average patients are more than 700 patients monthly. This study assume that the interpersonal communication might be the cause. In constructing the argument, this paper will use the Humanistic Perspective Theory and the Theory of Value Expectancy. Quantitative approach will be the method and the survey will use the accident sampling among customers. It was found that the Impact of Interpersonal Communication Sari Asih Hospital toward Customer Satisfaction is has possitive effect.
\end{abstract}

\section{Introduction}

The presence of Public Relations in organization or company is to establish a harmonious relationship and build a positive public opinion of the organization or company. The relationship in this point is mutual relationship between company with internal and external community. Internal community is associated with giving information and motivation to investors and employees as well as to listening their input. While External Public Relations activities is supposed to strengthen the relationship or maintain the loyalty of customers, suppliers, governments, and communities. Communication is considered as an important component in the establishment of business relationships. "However, these variables are often assumed or taken for granted and consequently overlooked as a component of relationship development" [1]. As well as the case of Sari Asih Hospital, eventually every company will seek to maintain their customers. Extra services is provide to make customers feels comfortable and satisfied. This approach is used to mantain customers. Another way is build a good relationship between company and its customers.

Customer Service as a frontline of companies, they are interact directly with the external public. Customer Service is represent to Public Relations in providing services such as: information, product sales and other things according to customer requirements. However, to be Customer Service is not easy because they have tobe able to recognize the characteristics of each customer and their needs. Therefore the most effective approach is interpersonal communication. The role of Customer
Service has become one of the determinants of customer satisfaction. Due to customer satisfaction is created not only from facilities and products provided by the company, but also related to the impression of the services provided by Customer Service, including of their communication skillsAs the research results of Hardianti showed that there was the impact of interpersonal communication Customer Service to customer satisfaction Kaltim Bank Syariah Branch Juanda Samarinda [2]. This paper would to examine how the interpersonal communication by Costumer Service has the ability to transform and build customer attitudes towards customer satisfaction. As well as in Sari Asih hospital Ciledug, since it began operating, the number of competitors increases. It is one of the challenges in retaining customers. The results of this research could be an evaluation for hospitals.

Health facility is holds very important role of public welfare in the region. One of the existing health facilities in Tangerang is Hospital. Referring to Law Number 44 Year 2009 regarding Hospital, the definition of a hospital is a health care institution for people with characteristics of its own which is influenced by the development of health science, technological progress and socio-economic life of society who must remain able to improve service more qualified and affordable for the people to manifest the degree of health as high. This means that, the Hospital is a health care institution which organizes personal health services in the plenary that provides inpatient, outpatient, and emergency department. According to data from the Central Bureau of Statistics Tangerang, in 2011 in the city of Tangerang

* Corresponding author: agungnawa@ymail.com 
there are 22 hospitals, 51 maternity hospitals, 185 polyclinics, 28 health centers, 11 health centers, 235 doctors and 287 practice of midwifery practice. Overall hospital in the city of Tangerang located in 22 Village and 10 districts. Development in the health sector supposed to make all levels of society can obtain health services easily and evenly. The existence of such efforts are expected to achieve a good degree of public health, which in turn increases productivity.

Table 1. List of Tangerang Hospital

\begin{tabular}{lll}
\hline & & Total \\
No & The Names of the Hospital & Patient \\
& & \\
\hline 1 & RS Usada Insani & 20.320 \\
2 & RS Mayapada & 6.611 \\
3 & RS Daan Mogot & 1.712 \\
4 & RS Aminah & 3.317 \\
5 & RS Sari Asih - Karawaci & 12.804 \\
6 & RS An -Nissa & 6.408 \\
7 & RSK Sitanala & 330 \\
8 & RSIA Keluarga Ibu & 698 \\
9 & RS Melati & 3.003 \\
10 & RS Bhakti Asih & 6.715 \\
11 & RSIA Mutiara Bunda & 1.473 \\
12 & RS Sariasih - Ciledug & 15.085 \\
13 & RS Mulya & 3.772 \\
14 & RS Medika Lestari & 12.888 \\
15 & RS Awal Bros & 7.033 \\
16 & RS Sari Asih - Sangiang & 7.442 \\
17 & RS Dinda & 3.990 \\
18 & RSIA Bunda Sejati & 906 \\
19 & RS Hermina & 3.046 \\
20 & RS Ariya Medika & 7.892 \\
21 & RS Aqidah & 1.491 \\
22 & RS Pratiwi & 2.049 \\
23 & RSIA Karunia Bunda & 5.414 \\
24 & RS Karang Tengah Medika & 62 \\
\hline & TOTAL & $\mathbf{1 3 4 , 4 6 1}$ \\
\hline SourceTangerang City Heath Department & $2016)$ \\
\hline
\end{tabular}

Source:Tangerang City Health Department (2016)

Sari Asih Hospital Ciledug is one of the hospitals in the region Ciledug Tangerang. This hospital is equipped with high-quality medical equipment and adequate facilities such as 155 room number, outpatient facilities, emergency departments and other medical support (http://aldintara.com/overview-rs-sari-asih-ciledug/ acces in 13 Januari 2017, $06.53 \mathrm{am}$ ). People take advantage of the presence of hospital. Base on fact, there is an increase from $41.74 \%$ to $71.09 \%$ on 2006 to 2016 . This conditions is mean a very potential market segments for health services. Problems faced by the hospital that stood since 2005 is still able to survive and thrive in the current conditions of the moment. Where competition similar business more competitive in the snatch customers. Customer Service equipped with knowledge of the sale of health products offered, ability to communicate well, dressed accordingly and keep the attitude to dealing with customers. With hope customers will feel comfortable and satisfied with the product and services.
In this section will describe the definition of Interpersonal Communications, Customer Service, the definition of Customer Satisfaction, Perspective Humanistic and The Affective Cognitive Consistency Theory.

\subsection{Interpersonal communication}

Simple overview of the communication process can be seen According to Hovland [3]; "communication is the process by which an individual (the communicator) transmits stimuli (usually verbal) to modify the behavior of other individuals (the audience)". According to Joseph A. DeVito [4]; "Interpersonal communication is the process of sending and receiving messages between two persons, or among a small group of persons, with some effect and some immediate feedback". Interpersonal communication that is intended in this research is an oral communication in a conversation conducted by Customer Service with customers in Sari Asih Hospital, Ciledug. The ideal process of interpersonal communication is where Customer Service know whether the service that provided could be well received by customers and get the responses that are positive or negative.

This is shown through verbal communication in a conversation feedback directly. Communicators know the response of communication at the moment and know with certainty whether the messages they sent was received or rejected. If not accepted, the communicator will provide greater opportunities to the communicant to ask.

\subsection{Customer service}

According to Effendy [5]; "customer service is one of public relations activities in carrying persuasive communication process conducted by a person to another person face to face in the work situation and in the organization. The aim is to arouse excitement and activity to work with the spirit of productive cooperation with feeling happy and satisfied". "In practice customer service function is as a receptionist, as deskman, as a salesman, a customer relations officer, and as a communicator" [6]. Customer service in this study is referred to those who conduct persuasive communication in providing information on health care services in Sari Asih Hospital, Ciledug.

\subsection{Customer satisfaction}

According to Kotler [7]; "customer satisfaction is feeling happy or disappointed someone caused by the performance or the result of a service that is perceived, compared with expectations. If the services earned less than expected, the customer will be dissatisfied, disinterested and disappointed to the provision of services is concerned. Meanwhile, if the services are perceived by customers more than they expected, customers will be satisfied". Customer satisfaction is obtained after the purchase and consumption. Then the researchers can conclude that customer satisfaction will 
be achieved if a service is considered satisfactory and can complement the needs of the customer according to the desired expectations. As is the customer in this study is, customers who use health care services at Sari Asih Hospital, ciledug.

\subsection{Prespective humanistic theory}

According to DeVito, that "the Perspective Humanistic approach presents those attributes needed to enhance bonding between individuals [4]. At the risk of being overly repetitious, these two aproaches are not opposites. They do represent two different ways of defining and approaching interpersonal communication effectiveness". Perspective Humanistic theory

assumes that individuals interact with one another, feel is linked to one another and do more communication actions. Conversely, individuals who do not have conflicting or interpersonal relationship, then it will only slightly even less in carrying out acts of communication. By using this theory, researchers can measure and determine how the interaction process of interpersonal communication will have cohesion and interactive. The process of interpersonal communication as a form of behavior can change from highly effective to ineffective, and at one time it could be worse communication and at other times could have been better. Five general qualities from this model: openness, empathy, supportiveness, positiveness, and equality [4]. (1) Openess; Referring to our ability to open up where there is a disclosure of information about ourselves that are usually far we cover, and to react honestly to the message that we receive, and referring to the feelings and thoughts that we have. (2) Empathy; is our ability to feel what others feel, try to experience what happened to the others from the viewpoint of the person without losing their own identity. (3) Supportiveness; is an atmosphere that is more directed to a support. (4) Positiveness; is showing positive behavior and praise the people who interact with you. Furthermore, (5) Equality; is felt that two or more people are actually similar in many aspects. The Humanistic models will use as a basis to determine the extent of interpersonal communication is able to create customer satisfaction interaction between the Customer Service Sari Asih Hospital Ciledug with customers.

\subsection{The affective cognitive consistency theory}

In this theory, examines the relationship between attitudes and beliefs [8]. It has been proposed that attitudes have an affective component (a positive or negative feeling toward the issue) and a cognitive component (beliefs or thoughts about the issue). Rosenberg stated that when the affective and cognitive components of an attitude are mutually consistent, the attitude is in a stable state. In other words, the strength of an attitude is determined by more than just the favourability of the attitude. This means that the strength of an attitude is influenced by the consistency or agreement between the affective and cognitive components of the attitude. Behaviour is generally more influenced by the hope of achieving something desired result (any positive incentives) of the impetus from within. Expectation value based on a balance between trust and evaluation. Value is defined as the quality of service of Customer Service. So the attitude of customers is the result of the evaluation of the services provided by officers. Customer Service with customer expectations will be a quality service. Additionally Customer Service should be able to put itself well to enable the smooth communication with customers, and the most important is the attitude of support and a positive attitude. There are several factors that affect customer satisfaction. (1) Customer expectations (desire customers to served with good and right). Customers very much hope that getting the best quality services. Quality services can be realized if an officer can serve customers by being polite and professional, have alacrity in serving customers, extensive knowledge about the company and have the alertness and speed and reliable in helping customers to solve customer problems, so as to satisfy the customer. And (2) The fact that customer acquired (Person Need or Individual Needs). Customers come to the Customer Service to get their basic service needs (Self Personality).

This expectation can be realized if the workers provide services that show a sense of caring to give individual attention to customers and understand customer needs. If the service provided is able to create a positive belief in customers, it will lead to customer satisfaction. Satisfaction with the quality of service that will reinforce the attitudes and foster customer loyalty to Sari Asih Hospital Ciledug. Customer satisfaction to Sari Asih Hospital Ciledug can be formed if the value of customer expectations can be fulfilled.

\section{Materials and methods}

\subsection{Research framework and hypotheses}

Based on the above framework, "the researchers made a temporary answer" [9]. Temporary answer (hypothesis) then must be verifiable. The hypothesis is determined based on the background of the problem, the subject matter, the theoretical basis and framework. Such as:

Ho, rxy $=0$ : There is no relationship between the interpersonal communication between Customer Service and customer satisfaction at Sari Asih Hospital, ciledug.

Ha, rxy $>0$ : There is a relationship between the interpersonal communication between Customer Service and customer satisfaction at Sari Asih Hospital, ciledug.

Fig. 1.

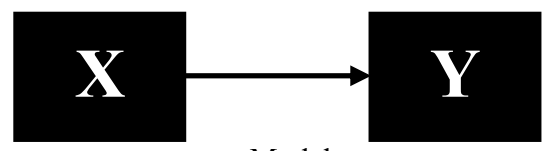

Research

Model

Information:

Independent variable $(\mathrm{X}) \quad=$ Interpersonal Communication

Dependent variable $(\mathrm{Y}) \quad=$ Customer Satisfaction 
In this case the independent variable is interpersonal communication Customer Service with customers. Indicators that can be developed from the theory that supports variable inter-personal communication Customer Service are: openess, empathy, supportiveness, positiveness, and equality. For the dependent variable is a variable that is affected or become due, because of the independent variables. In this case is customer satisfaction, using indicators: the desired expectation and personal need.

This paper uses the paradigm of positivism. According to Neuman, "Positivism paradigm is used to show the relationship between the variables to be studied and symptoms of causal relationship" [10]. Positivism is used to reveal the truth of reality and how reality is running. Information on the truth directly to the researchers asked respondents without the intervention of researchers. The information then can be observed, measured accurately, and the researchers tested the hypothesis through the analysis of numbers of measurement results. For this type of research is quantitative eksplanatif. This type of research is able to describe the relationship between research variables and conduct testing hypotheses that have been formulated previously.

\subsection{Sample and Data Collection}

Data collection and analysis is using quantitative method. The research instrument used questionnaire. The questionnaire aimed to obtain information from respondents. The respondents of this study are customer Sari Asih Hospital Ciledug. The survey was conducted on December, 2016. 985 total of patients into the study is the population. And due to the limitations of time, cost and effort, researchers determined the sample. "Population is represented by the sample. The sample is part of the population" [9].

According to Guilford, "statistics is a way of looking at a population's behavior by taking a sample" [11]. It's usually impossible to survey every member of a population because of money or time. That's where Slovin Formula comes in. The formula used to determine the sample Slovin, with an error rate of $10 \%$.

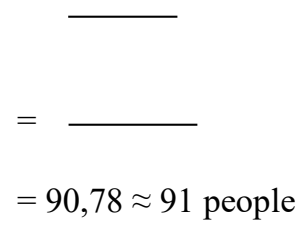

Information :

$$
\begin{aligned}
& \mathrm{n}=\text { Sample } \\
& \mathrm{N}=\text { Population } \\
& \mathrm{e}=1 \%, 2 \%, 3 \%, 4 \%, 5 \%, \text { or } 10 \%
\end{aligned}
$$

Sampling technique used in this research is through accidental sampling, to anyone who happened to meet researchers and seen people who happened suitable as a data source. Data collection techniques in this study using two types of data. First Primary data in the form of a questionnaire. The questionnaire will measure customers. perception of the level of satisfaction of respondents by giving a set of questions or a written statement to answer. The second type of data is from of literature studies. In this technique the researchers conducted a literature study to complete the data. Examples of secondary data are theories and data hospital related to the study. The collection of data through books related to the title of research and other sources (internet). As well as researchers compared with reference materials earlier study with the same problem with what the researchers carefully. In addition, researchers get information about the patient data from the Sari Asih Hospital Ciledug.

\subsection{Measurement}

To Analysis the questionnaire data is using inferential statistical tests. "Inferential test aims to explain the relationship between two or more variables" [12].

Statistical tests were performed with use of statistical data processing program (SPSS). The early stage of testing is to test the validity and reliability of the questionnaire. If not valid and reliable, the researchers need to revise the research instrument. Afterwards, the instrument spread back up to obtain valid and reliable results. Measurement opinions of respondents used a scale developed by Likert Rensis. This scale is called Likert Scale. "Likert scale used to measure attitudes, opinions, and perceptions of a person or of a phenomenon" [10].

Table 2. Likert Scale

\begin{tabular}{ll}
\hline Scale & Values \\
\hline Strongly Agree & 5 \\
Agree & 4 \\
Doubtful / No Comment & 3 \\
Disagree & 2 \\
Very Disagree & 1 \\
\hline
\end{tabular}

Source: Sugiyono (2009)

\subsection{Data Analysis}

This section describes the results of statistical tests. Not all tests performed in the statistics. Relevant tests to the needs of the research purpose only. Among others are a test of Validity and Reliability, Correlation and Regressions. Validity was conducted to determine the extent to which the instrument is able to measure what we want to measure. Is the measuring instrument that can measure the properties of the object that we examine. "While reliability to measure the consistency of the answers to the questionnaire" [10]. According to the table the value of r-Product Moment, the obtained limit r-table is 0,206. Significant level using $10 \%$, with the number of respondents 91 people.

Table 3. Validity Test Result 


\begin{tabular}{|c|c|c|c|c|}
\hline \multicolumn{5}{|c|}{$\begin{array}{l}\text { Interpersonal Communication Customer Service } \\
\text { (Variable X) }\end{array}$} \\
\hline No & Statement & $\begin{array}{c}\text { r- } \\
\text { values }\end{array}$ & $\begin{array}{c}\text { r- } \\
\text { table }\end{array}$ & Conclusion \\
\hline P1 & $\begin{array}{l}\text { Customer } \\
\text { Service provide } \\
\text { an explanation } \\
\text { to customers } \\
\text { openly } \\
\text { Customer }\end{array}$ & 0.409 & 0.206 & Valid \\
\hline $\mathrm{P} 2$ & $\begin{array}{l}\text { Service } \\
\text { provides } \\
\text { friendly service }\end{array}$ & 0.665 & 0.206 & Valid \\
\hline P3 & $\begin{array}{l}\text { Customer } \\
\text { Service serves } \\
\text { customers not } \\
\text { only face-to- } \\
\text { face interaction } \\
\text { but with other } \\
\text { media such as } \\
\text { telephone or } \\
\text { email }\end{array}$ & 0.531 & 0.206 & Valid \\
\hline P4 & $\begin{array}{l}\text { Customer } \\
\text { Service is able } \\
\text { to greet by } \\
\text { name the } \\
\text { customer }\end{array}$ & 0.599 & 0.206 & Valid \\
\hline P5 & $\begin{array}{l}\text { Customer } \\
\text { Service respond } \\
\text { each question or } \\
\text { customer } \\
\text { complaints } \\
\text { immediately }\end{array}$ & 0.484 & 0.206 & Valid \\
\hline P6 & $\begin{array}{l}\text { Customer } \\
\text { Service serve } \\
\text { customers with } \\
\text { fast, skilled, } \\
\text { accurate, and } \\
\text { thorough }\end{array}$ & 0.515 & 0.206 & Valid \\
\hline P7 & $\begin{array}{l}\text { Customer } \\
\text { Service serve all } \\
\text { customers } \\
\text { without any } \\
\text { distinction }\end{array}$ & 0.539 & 0.206 & Valid \\
\hline P8 & $\begin{array}{l}\text { Customer } \\
\text { Service } \\
\text { seriously listen } \\
\text { every customer } \\
\text { information }\end{array}$ & 0.574 & 0.206 & Valid \\
\hline P9 & $\begin{array}{l}\text { Customer } \\
\text { Service } \\
\text { responds to } \\
\text { customer } \\
\text { demand with } \\
\text { immediately }\end{array}$ & 0.540 & 0.206 & Valid \\
\hline P10 & $\begin{array}{l}\text { Customer } \\
\text { Service is able } \\
\text { to provide } \\
\text { solutions } \\
\text { Customer }\end{array}$ & 0.600 & 0.206 & Valid \\
\hline P11 & $\begin{array}{l}\text { Service serving } \\
\text { with friendly }\end{array}$ & 0.533 & 0.206 & Valid \\
\hline P12 & $\begin{array}{l}\text { Customer } \\
\text { Service } \\
\text { concerned with } \\
\text { customer } \\
\text { complaints }\end{array}$ & 0.682 & 0.206 & Valid \\
\hline
\end{tabular}

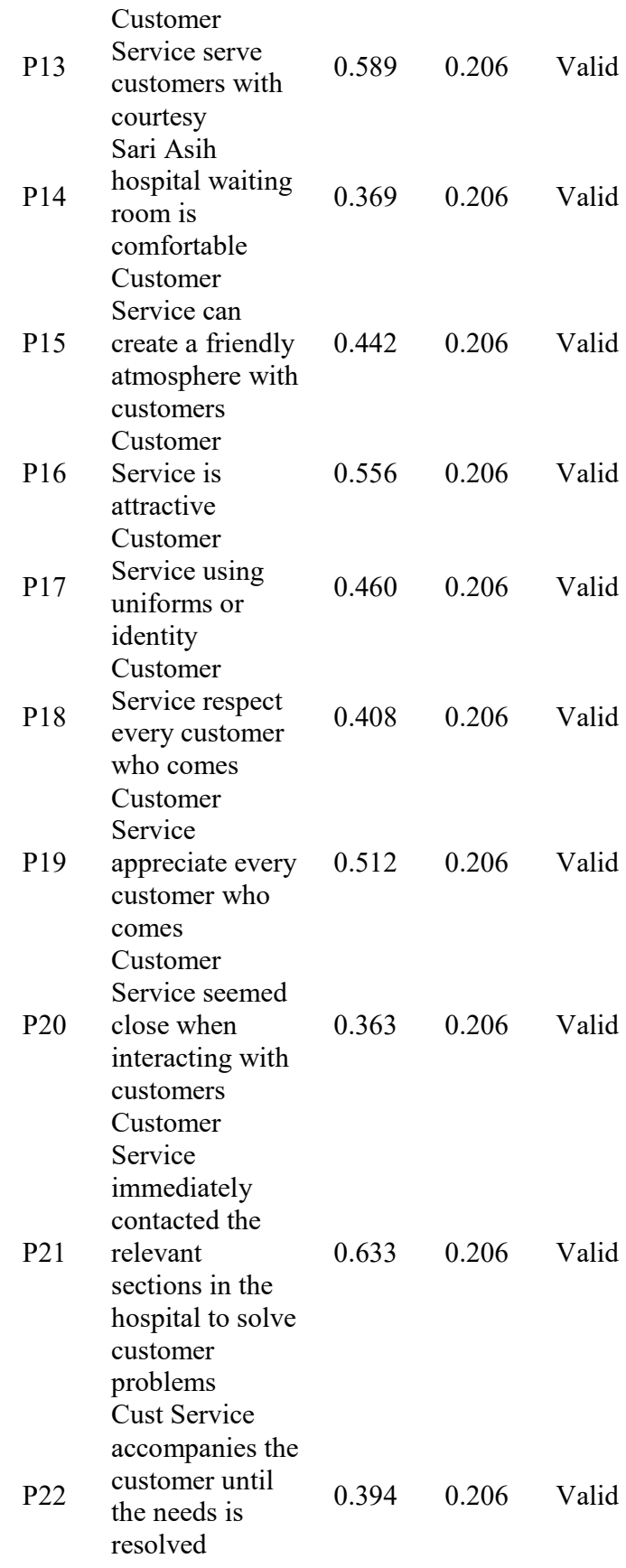

\begin{tabular}{lllll}
\hline \multicolumn{3}{l}{ Customer Satisfaction (Variable Y) } & \\
\hline No & Statement & $\begin{array}{l}\text { r- } \\
\text { values }\end{array}$ & $\begin{array}{l}\text { r- } \\
\text { table }\end{array}$ & Conclusion \\
\hline & $\begin{array}{l}\text { Customer } \\
\text { Service } \\
\text { accompanies } \\
\text { customer until } \\
\text { the issue is } \\
\text { resolved } \\
\text { Customer } \\
\text { Pervice looks }\end{array}$ & 0.698 & 0.206 & Valid \\
P24 & & & \\
reliable in \\
serving \\
customers \\
$\begin{array}{l}\text { Customers get } \\
\text { clear } \\
\text { information } \\
\text { from Customer }\end{array}$ & 0.613 & 0.206 & Valid \\
P25 & 0.553 & 0.206 & Valid \\
& & & \\
\end{tabular}




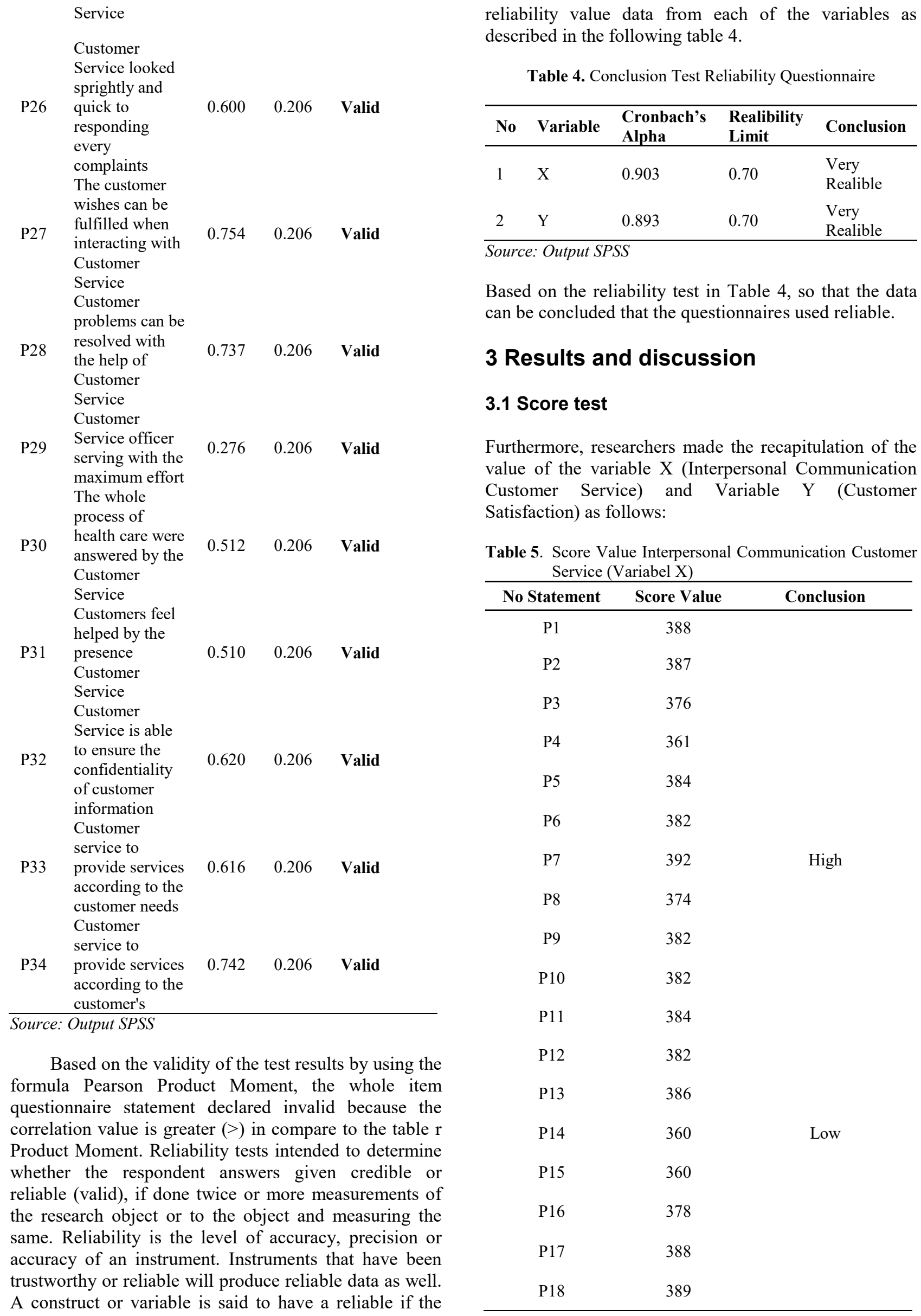

Cronbach Alpha $>0.70$. From these test results obtained 


\begin{tabular}{ll}
\hline P19 & 388 \\
P20 & 380 \\
P21 & 383 \\
P22 & 375 \\
\hline
\end{tabular}

Source: Output SPSS

Table 5, shows that the average value of respondents to the overall indicator Interpersonal Communication Customer Service (variable X) are:

$$
\begin{aligned}
\text { Presentage } & =(\text { Total Score : Skor Maximum }) \times \\
& 100 \% \\
= & (8369: 10.010) \times 100 \% \\
= & 83.60 \%
\end{aligned}
$$

Based on the percentage calculation above, the percentage of votes obtained by the magnitude of respondents to the Interpersonal Communication is $83.60 \%$. When adjusted for interval continuum, then the results are included in the category of Good. That means, respondents said Interpersonal Communication Customer Service runs well enough to be able to grow Customer Satisfaction at Sari Asih Hospital, Ciledug.

Table 6. Score Value Customer Satisfaction (Variabel Y)

\begin{tabular}{ccc}
\hline No Statement & Score Value & Conclusion \\
\hline P23 & 364 & \\
P24 & 368 & \\
P25 & 370 & \\
P26 & 369 & \\
P27 & 362 & \\
P28 & 354 & High \\
P29 & 377 & \\
P30 & 371 & Low \\
P31 & 349 & \\
P32 & 366 & \\
P33 & 360 & \\
P34 & 365 & \\
\hline
\end{tabular}

Source: Output SPSS

Based on the results of the development of As for the variable Y (Customer Satisfaction) Table 6, shows that the average value of respondents to the overall indicator is the establishment of Customer Satisfaction:

$$
\begin{aligned}
\text { Presentage } & =(\text { Total Skor : Score Maximum }) \times \\
& 100 \% \\
= & (4753: 5915) \times 100 \% \\
= & 80.35 \%
\end{aligned}
$$

Percentage of respondents to the Customer Satisfaction ratings of $80.35 \%$. When adjusted for the value continuum interval then the results are included in the category of Good. That means, the respondents said that increasing customer satisfaction is good enough for their interpersonal communication Customer Service interaction with customers.

\subsection{Correlation analysis}

Acquisition of data that has been given a score and then processed by using SPSS (Statistics Package for Social Science). Further analysis is reinforced by regression analysis to determine the influence that occurred. To provide interpretation of the correlation coefficient is determined large or small, it is guided by the provisions contained in the following table:

Table 7. ntepretation Coefisien Correlation

\begin{tabular}{cc}
\hline Coefficients Correlation & Level of Correlation \\
\hline $0.00-0.199$ & Very low \\
$0.20-0.399$ & Low \\
$0.40-0.599$ & Moderate \\
$0.60-0.799$ & Strong \\
$0.80-1.00$ & Very Strong \\
\hline
\end{tabular}

Source: Sugiyono [13]

"Correlation is a statistical tool that can be used to compare measurements of two different variables, in order to determine the degree of correlation between the variables" [14]. Correlation test the hypothesis that the researcher will answer submitted. The results of correlation test variables $\mathrm{X}$ and $\mathrm{Y}$ are as follows:

Table 8, Correlations Test Result

\begin{tabular}{llcc}
\hline & Variables & X & Y \\
\hline $\mathrm{X}$ & Pearson & & \\
& Correlation & 1 & $.676^{* *}$ \\
& & & \\
& Sig. (2-tailed) & & .000 \\
$\mathrm{~N}$ & 91 & 91 \\
$\mathrm{Y}$ & & \\
& Pearson & & \\
& Correlation & $.676^{* *}$ & \\
& & & \\
& Sig. (2-tailed) & .000 & 91 \\
\hline
\end{tabular}

Source: Output SPSS

Based on calculations using SPSS (Statistical Package for Social Science) in the above table, it can be a correlation between these two variables, where the value of the correlation coefficient (r) discovered is 0.676. Means the value of this correlation coefficient correlation between the impact of interpersonal communication Sari Asih Hospital toward customer satisfaction is has possitive effect.

\subsection{Regression analysis}

Table 9 showed that it can be said the influence of variable $\mathrm{X}$ (Interpersonal Communication Customer 
Service) with Variable Y (Customer Satisfaction) at Sari Asih Hospital Ciledug are at the level of the Strong correlation coefficients, located at the level of 0.60 to 0.799 with value a coefficient of 0.676 (using Table 7 for the intepretation). The results of $\mathrm{R}$ Square $=0457$ or in the form of a percentage of $0457 \times 100 \%=45.7 \%$, while the remaining $100 \%-45.7 \%=54.3 \%$ influenced by other factors.

Table 9: Regression Test Result

\begin{tabular}{|c|c|c|c|c|}
\hline Model & $\mathbf{R}$ & $\begin{array}{c}\mathbf{R} \\
\text { Square }\end{array}$ & $\begin{array}{l}\text { Adjusted R } \\
\text { Square }\end{array}$ & $\begin{array}{l}\text { Std. Error of } \\
\text { the Estimate }\end{array}$ \\
\hline 1 & $.676^{\mathrm{a}}$ & .457 & .451 & 4.20009 \\
\hline
\end{tabular}

From the research, there is a strong relationship between interpersonal communication Customer Service Sari Asih Hospital Ciledug to customer satisfaction. This is consistent with the explanation of the Perspective Humanistic theory. That individuals interact with one another will find it has a relation to one another. So that they will more act of communication. Instead, individuals are conflicting (not having interpersonal relationship) will be less in carrying out acts of communication. Interpersonal communication between the Customer Service to customers will be successful if both parties have a mutual openness, empathy, positive attitude, support, and similarity. Furthermore, by using the theory of interpersonal communication effectiveness of humanistic perspektive can be a material evaluation. So that it can be seen the extent to which the communication is going well and is able to improve customer satisfaction Sari Asih Hospital Ciledug.

According to Kotler [7]; customer satisfaction is the customer response to the evaluation of the perceived between prior expectations or other performance expectations and actual performance services perceived after wear. Then the researchers can conclude that customer satisfaction will be achieved if a service is rated to meet customer needs in accordance with the desired expectations. By measuring the level of customer satisfaction then the Sari Asih Hospital Ciledug can provide better service, effectively, and efficiently.

\section{Conclusion}

From the analysis concluded that the impact of interpersonal communication toward customer service Sari Asih hospital Ciledug in Best categories. It is based on a statistical calculation of all questionnaires filled out by respondents. This means that the interaction of customer service rated positively to customers. The presence of Customer Service Sari Asih hospital Ciledug is important as a first gate that interact directly with the customer (patient). Cutomer Service could provide a solution of confusion cutomer. Positive impression will be embedded in the customer mind after interacting with Customer Service. This impression will they bring when interacting with other parts of the Sari Asih Hospital Ciledug. Thus the function of public relations in shaping the relationship and strengthen the positive image is reached. It is represented by the presence of Customer Service. Interpersonal communication process can be used to measure customer attitudes after interacting with Customer Service. It becomes necessary for the Customer Service have an attitude of empathy in evaluating their action. Evaluation can be done by looking at an attraction or rejection of customers. Because based on theory, is a response to customers from any activities with Customer Service. With such a response, it can be used in determining the next action or strategy to achieving customer satisfaction. However, simultan evaluation and continuous innovation becomes a solution in the face of competition from other hospitals. By continuing to realize the achievement of the quality of public health. As their vision and mission over the years.

According to [7] means that when the customer has a feel for how the service Customer Service customer will evaluate it. Customers will be satisfied if their expectations are met. And then customers will do more positive behavior. For example, if they are sick, Sari Asih Hospital Ciledug services be an option in his heart and the first choice. Behavioral word of mouth they can do anyway. Customers will recommend others about health care in Sari Asih Hospital Ciledug compassion. Many factors affect satisfaction. In this study focused on the personal form of communication between Customer Service. What is the role of doctors, nurses, facility, speed drug services and so interesting to study. So this into recommendations for the next research.

\section{References}

1. P. R. Andersen, Journal of Business \& Industrial Marketing, 1(2), 167-82, (2001)

2. O. Hardianti, Octaviani, ejournal ilmu komunikasi fisip unmul.ac.id, 2016, 4(3), 237251, (2016)

3. C. J. Hovland, I. L. Janis, H. H. Kelley, Communication and Persuasion, (CT: Yale University Press, New Haven, 1953)

4. J. DeVito, Komunikasi Antar Manusia, 2nd ed., (Professional Book, Jakarta, 2007)

5. O. U. Effendy, Ilmu Komunikasi Teori Dan Praktek (PT Citra Aditya Bakti, Bandung, 1999)

6. Kashmir, Etika Customer Sevice (Raja Grafindo Persada, Jakarta, 2005)

7. P. Kotler, K. L. Keller, Manajemen Pemasaran Jilid 1, 13rd ed., (Bob Sabran, MM. Erlangga, Jakarta, 2009)

8. M. J. A. Rosenberg, C. I. Hovland, Attitude organization and change, (CT: Yale University Press, New Haven, 1960)

9. J. W. Creswell, Research Design, 3rd ed., (Pustaka Pelajar, Yogyakarta, 2010)

10. W. L. Neuman, Social Research Methods, 5th ed., (Pearson Education, Boston, 2003) 
11. J. P. Guilford, B. Frucher, Fundamental Statistics in Psychology and Education, (MC Graw-Hill, New York, 1973)

12. R. E. Walpole, Pengantar Statistika, 3rd ed., (Gramedia Pustaka Utama, Jakarta, 1992)

13. Sugiyono, Metode Penelitian Kuantitatif Kualitatif dan R\&D, (Alfabeta, Bandung, 2009)

14. D. Kleinbaum, L. L. Kupper, K. E. Muller, Applied Regression Analysis and Other Multivariable Methods, 2nd ed., (PWS-Kent, Boston, 1988)

15. Al-Hersh, A. Mohammad, Abdelmo'ti Suleiman Aburoub, Abdalelah S. Saaty, Journal of International Journal of Academic Research in Business and Social Sciences, 4(5) 67-100, (2014)

16. Cangara, H. Hafied, Pengantar Ilmu Komunikasi (PT Raja Grafindo Persada, Jakarta, 2014)

17. J. Griffin, Customer Loyalty: Menumbuhkan dan Mempertahankan Kesetiaan Pelanggan, (Erlangga, Jakarta, 2000)

18. F. Jefkins, Frank, Public Relations, 5th ed. (PT Gelora Aksara Pratama, Jakarta, 2003)

19. Kueh, Shirley, A. H. Bahar Pengiran Bagul, Journal of International Journal of Research in Management \& Technology, 3(4),126-135, (2013)

20. A. Liliweri, Perspektif Teoritis Komunikasi Antar Pribadi, (PT Citra Aditya Bakti, Bandung, 2004)

21. S. W. Littlejohn, (Theories of Human Communication, 7th ed. Wadsworth, New Mexico, 2002)

22. K. Miller, Communication Theories, (McGraw Hill, New York, 2001)

23. R. West, Richard, Introducing Communication Theory, (Salemba Humanika, Jakarta, 2010)

24. V. A. Zeithaml, Bitner, Service Marketing (The Mc Graw Hill Companies, New York, 1996) 